\title{
The images of politicians in the language consciousness performed in the English and German newspaper and journalistic discourses
}

\author{
Denis Lapenkov, Olga Oleinik*, and Olga Utkina \\ Orsk Humanities and Technology Institute (the Branch of) Orenburg State University, \\ 462419, Omsk, Russia
}

\begin{abstract}
In the modern era of mass politicization of the public consciousness of the media, in addition to forming an opinion on political events, it also performs the function of manipulating the public consciousness. Of particular interest in this influence are the images of leading politicians. Images of politicians in the media influence the formation of opinions about the political situation in the country and in the world as a whole. In order to analyze the images of politicians in the media and to identify the deep meaning in the presentation of images of politicians, the authors of the article turn to text materials of electronic versions of social and political newspapers and magazines (The Guardian, Daily Mail, Telegraph, Focus, Zeit, Spiegel), using the conceptual method analysis and contextual analysis method. The presentation of images of politicians reveals value meanings of sympathy and antipathy. The authors of the article attempt to identify moments in the representation of the images of politicians, where they generate additional meaning that has an emotional impact on public opinion.
\end{abstract}

\section{Introduction}

The media is represented not only by the print press, television and radio broadcasting. A vast array of information at the present stage supplies electronic resources that are publicly available and do not require a subscription to them. According to the experts in the field of political linguistics, E. V. Budaev and A. P. Chudinov: "The intensive development of information technologies, the growing role of the media, and the increasing dramatization of political activities contribute to increasing public attention to political discourse" [1].

The discourse of print media performs the following communicative functions: influencing, informative, evaluative, the function of criticism, the formation of public opinion. At the same time, the leading communicative attitude of the author of an article in a newspaper and journalistic discourse is influential, and the information content is only a background. Increasingly, factual information gives way to emotional information. The author of the article expresses the state of his consciousness in the verbal form and thus affects the consciousness of the addressee with the help of verbal means of expression.

\section{The concept of "Prime Minister Theresa May"}


The front pages of printed editions traditionally cover the main political events, the main participants of which are certain political figures, whose image is of great importance for foreign and domestic policy. The image of politicians is represented by language means. According to A. A. Potebnya, "with the help of a word, a person will again recognize what has already been in his mind. He simultaneously creates a new world out of the chaos of impressions, and increases his strength to expand the limits of this world" [2]. The generation of a "new" image occurs through language as the main channel of information in print media. The author creates a "new" image using various language means, fixes it in the linguistic consciousness. N.F. Alefirenko argues that linguistic consciousness "uses verbalized knowledge, which serves as a means of activating the relevant elements of cognitive consciousness"[3]. If linguistic consciousness is considered as a "verbally shaped reflection of reality in consciousness", then the image of a politician as part of the surrounding world is perceived by the addressee through refraction in the author's mind, that is, in a revised, reflected form. This happens because it is not the image as a whole that is subjected to reflection, but only the parts that make up it, which the author considers most important at the moment and in a certain situation. The conceptual and constructive core of any conceptual space (concept sphere) and, as a result, linguistic consciousness is, according to N.F. Alefirenko, concept as an element of consciousness. The concept is a structural-semantic element of linguistic consciousness. The concept encodes in its structure the entire set of syntagmatic, paradigmatic and ethno-cultural connections of semantic entities within the framework of consciousness. It follows that the anthropological concept is part of linguistic consciousness. At this time, the British socio-political conceptual space determines one identification component - the concept of "Prime Minister Theresa May", which is the most relevant for the national consciousness of Great Britain.

Based on the articles posted on the pages of English newspapers during Theresa May's term as British Prime Minister (from July 2016 to July 2019), we are going to identify the constitutional features of the Prime Minister Theresa May concept to determine the way the image of the politician is objectified in print media. The analysis will be based on the development of the concept structure by Z.D. Popova and I.A. Sternin [4].

The image of politics is objectified with the help of evaluative vocabulary. Thus, the image of the British Prime Minister is created by certain vocabulary, giving a clear axiological interpretation: a thinly veiled attack [5]; The beleaguered prime minister, whose authority has been shattered by the double rejection of her deal and the humiliation of a delay to Brexit day [6]; her Brexit-wracked premiership is coming to an end; last-ditch effort; her desperate struggle to get the UK out of the EU, her notorious coughing conference speech [7]; Calling time on a turbulent three-year premiership punctuated by revolts and resignations [8]; Her high-stakes pledge came on another dramatic day in Westminster [9]; 'frivolous' demands [10]; a bloody difficult woman [11]; Outgoing-PM [12].

The image of the British Prime Minister is generally based on the characteristics of her position (the humiliation of a delay, a turbulent three-year premiership, beleaguered prime minister), behavior (a thinly veiled attack, last-ditch effort, desperate struggle), personal (a bloody difficult woman) and professional qualities (one of the most inadequate and disastrous leaders, notorious coughing conference speech). At the same time, using the author's "a bloody difficult woman", the author intends to demean the status of a politician, emphasizing gender. Subjecting the selected lexical units of the estimated categorization, it can be stated that they belong to the means of verbalization of the negative evaluation of the object and represent the sign "bad".

Lexical units that convey the meliorative assessment of the British Prime Minister and, thus, representing the cognitive signs of "good", are significantly inferior in the newspaperpublicist discourse to a derogative assessment and mainly concern the appearance of a 
politician: May is the British Angela Merkel. After all, they have both worn 'mint and turquoise outfits' [11]; we have a female prime minister, a very clean-looking lady [11]; a wholly unique woman [11]; chooses her words with feline delicacy too [13]; her language becomes uncharacteristically vivid [13].

The next way to represent the image is a metaphor, which, according to N.D. Arutyunova, "is the key to understanding the fundamentals of thinking and the processes of creating not only a national-specific vision of the world, but also its universal image" [14]. The image of the Prime Minister of Great Britain is objectified through various hyphenations of similarity: Speaking with the newspaper reporter, the Prime Minister was asked "how she steeled herself for the job and the tough decisions ahead" [15]. Thus, in terms of frequency of use, the activity of the Prime Minister is compared with a war or a game with which she does not cope well "she faced a heavy defeat" [16]. In T. May's behavior they find similarities with inanimate objects (wood, metal), emphasizing its secrecy and perseverance, and with animals, in particular with a cat: "and her eyes narrow briefly: catlike and wary" [13]; May, it turns out, has been quarrelling with Thatcher for decades, proving death is no bar to a good catfight [11].

The metaphors presented in the latest editions of newspaper texts contain a clearly derogative assessment of the activities of the Prime Minister of Great Britain and carry a sign of "bad." According to A.P. Chudinov and E.V. Budaev, metaphors help us transform the linguistic picture of the world existing in the mind of the addressee, introduce a new categorization into the presentation of seemingly well-known phenomena. Besides, metaphors represent a vivid assessment of reality [17].

In close connection with metaphorical comparisons, idioms are used. Newspaper texts are replete with figurative phraseology, which also carries an evaluative character: came to Brussels as a lame duck leader [18]; has played her final desperate card to tame the Brexit rebels in her warring party [9]; Mrs May finally fell on her sword, Andrea Leadsom put the final nail in Mrs May's political coffin, Theresa May repeatedly broke down in tears today [7]; Some at Westminster accuse the PM of seeking to tie the hands of her successor [19].

The analysis of the phraseological units showed that the main accentuation is the idea that T. May's tenure as prime minister is coming to an end, while the cognitive signs of "bad" relate to the actions of the politician.

Thus, considering the received conceptual and figurative components of the "Prime Minister Theresa May" concept, we define its structure: the core of the concept is "the head, the leader, the ruler"; the informational content includes the following components - a woman, behind her husband, shows inflexibility and rigidity in decision-making, makes loud public statements, leads a desperate struggle, has ruined her political career. The interpretation field (periphery) of the "Prime Minister Theresa May" concept is as follows: stubborn, persistent, inflexible, cautious, terse, poor, carrying destruction, discord, inadequate, strong, can destroy a country, need to leave office, leave office, Tory, conservative.

The presented analysis makes it possible to understand the content of the "Prime Minister Theresa May" concept in the English language consciousness and, thus, to get a complete picture of the image formed in the newspaper and journalistic discourse.

\section{Creating the image of a politician in the media}

The media is the creator of a certain image of politicians. Modern media can influence the mood of society, i.e. perform the manipulation function. The images of political figures presented in the media are perceived by the reader as their opinion about these people. The image of a politician created in the mass media forms a positive or negative attitude of the public to this political figure. This relation is influenced using semantic units, which are used 
in the environment with the name of a politician. For example, in the German media the name of V.V. Putin is most often encountered with the following semantic units: confrontation, regional wars, nuclear threat, war in the east of Ukraine, bombardment in Syria, cyber attacks: In einer Zeit, in der unsere politische Aufmerksamkeit durch Klimawandel, Migrationskrise, EU-Krise und viele andere Probleme gefangen genommen ist, die gemeinsame Zusammenarbeit fordern, bereitet sich Russland unter Putin - völlig grundlos - auf regionale Kriege in Europa vor, die es mit Kernwaffendrohungen siegreich beenden will, Ziel des russischen Plans sei es, die Konflikte mit dem Westen zu suchen und das Geschlossensein der westlichen Allianz zu ruinieren [20]. $-<$ At a time when our political attention is focused on such issues as climate change, the migration crisis, the eurozone crisis and many other problems that require a joint solution, Russia is preparing for Putin - without a cause - for regional wars in Europe planned to end victoriously with the help of nuclear threats, the goal of the Russian strategy is to confront the West and undermine the unity of the Western alliance.>

Unter wachsendem wirtschaftlichen Druck sucht der russische Chef die Wiederannäherung an Europa - nach der Besetzung der Krim, dem Krieg in der Ostukraine, dem Abschuss des Flugzeuges MH-17, den Bombenangriffen in Syrien und verschiedenen Cyberattacken [21]. - <With growing economic pressure, the Russian president is seeking rapprochement with Europe after the occupation of the Crimea, the war in eastern Ukraine, the crash of the MN-17 passenger plane, bombing in Syria and all sorts of cyber attacks>.

V.V. Putin is accused of fomenting a war in the east of the Ukraine, of crashing the Malaysian Boeing in the Donbas region, interfering in the American elections, of hacker attacks. Such information forms a negative attitude of the readers towards him, demonizes him, attributes to him the image of the enemy. The image of politicians is both a reflection of reality and is formed purposefully by media representatives. Peter Stiegnitz argues that public opinion is formed through political lies, which are based on the goals and interests of the current government. The media is regarded as the fourth branch of government, along with the three classical - legislative, executive and judicial - but the fourth branch has a greater influence not only on the three branches mentioned, but also on political and economic decisions [22].

The image of the state in the world arena and the image of its leader are inextricably linked to the situation in the world. According to M. R. Zheltukhina and A.V. Omelchenko the formation of the political image of the state in its internal media limits can be fully controlled and aligned according to the scheme. In the absence of the created internal image, it is impossible to fully trace and correct the external image of the state. It is much more difficult to track and correct the image of the country abroad in foreign media [23].

The researchers note that the political situation has a significant influence on the image of the state in foreign mass media. They also note a high role in the realization of the image of the state of already established stereotypes that exist in the mass consciousness.

And the image of Russia on the world stage is characterized by German media in the following way: Die Wirtschaftssanktionen sind die Reaktion auf das völkerrechtswidrige Verhalten der russischen Regierung auf der Krim und in der Ostukraine [24]. - < Economic sanctions are a reaction to the behavior of the Russian government, which undermines international law in the Crimea and in the east of Ukraine.>

To create the images of politicians and the image of the country, various linguistic units are used in the media. Among them are the following means of artistic expression: metaphors, metonymy, epithets, antonomasia, allusions, idioms.

Metonymy: Aber jeder Weg nach Europa führt durch Merkel. Dieses kennt Putin [21]. $<$ The road to Europe leads through Merkel. And Putin knows this. $>$

Epithets: Seit Jahren arbeiten Merkel und Kramp-Karrenbauer, die wegen ihres nüchternanalytischen Politikstils miteinander verglichen werden, eng zusammen [25]. In this 
example, the manner of behavior in politics of Merkel and the new Minister of Defense, Kramp-Karrenbauer, is characterized as calm and analytical.

Antonomasia: Der Kreml-Chef betreibe permanente Provokation, schüre Konflikte und destabilisiere, indem er Krisen unterschwellig provoziere [26]. - < The Kremlin chief constantly engages in provocations, inflames conflicts and destabilizes, while he implicitly provokes crises.>

In another example that we find in the New York Times, Merkel was named «die letzte Verteidigerin des liberalen Westens» [27]. $-<$ the last defender of the liberal West $>$.

Allusion: Natürlich, Angela Merkel ist nicht die alleinige Erfinderin dieser Politik, aber gemeinsam mit ihrem Finanzminister Wolfgang Schäuble, diesem Breschnew des Neoliberalismus, stand sie im letzten Jahrzehnt wie niemand sonst für diese Politik [27]. $<$ Of course, Angela Merkel was not the only inventor of this policy, but along with her finance minister Wolfgang Schäuble, this Brezhnev of neoliberalism, she defended this policy like no other in the last decade. - This example hints that Wolfgang Schäuble is similar to Brezhnev in allowing good times to turn into bad ones.

Metaphor: Putin ist ein wandelndes Geheimnis. Russlands Präsident lässt sich nicht in die Karten schauen [28]. $-<$ Putin is a walking secret. The Russian president will not give anyone his plans.> To convey a more vivid imagery in this example, the author also uses a phraseological unit «sich nicht in die Karten schauen lassen».

These language expressive means can be viewed as a way of knowing, explaining, interpreting and evaluating political events.

\section{Conclusion}

The images of politicians are presented in the media already in the form processed in the minds of the author of the article. At the same time, not the whole image is subjected to processing, but only the constituent parts of the image; these key points are currently of the greatest informational importance. By placing accents when presenting an image of politicians, using language means for this purpose (metaphors, metonymy, epithets, idioms, antonomasia, allusions), the required image of the politician is created. The names of politicians act as key units, and their environment or the use of certain vocabulary in media reports is selected with a certain intent. In this moment, a certain additional meaning is generated, which has an emotional impact on public opinion. Through this mechanism, the media influence the mood of civil society. The manipulative influence is carried out not only when submitting information to the direct activities of the politician, but also the information about the personal life, external qualities, health status, and more goes into circulation. Media capabilities are used purposefully to increase the rating of the ruling political elite. Mass communication today has considerable symbolic power. This is manifested in the imposition on the masses of a certain vision of the world by the power of the word through the creation of the desired images on the political scene. The images of politicians in the media created by this influence the formation of opinions regarding the political situation in the country and in the entire world.

\section{References}

1. E. Budaev, A. Chudinov, The issues of cognitive linguistics, The cognitive theory of metaphor at the present-day stage of development, 4 (013) 54 - 57 (2007).

2. A. Potebnya, From the notes on the theory of linguistics, 625, (1905).

3. N. Alefirenko, Linguistics and culture: value and meaning space of a language, 288, (2010). 
4. Z. Popova, I. Sternin, Cognitive linguistics, 315, (2007).

5. The Guardian, Theresa May Makes Veiled Attack on Boris Jonson Brexit Policy, 30.06, (2019).

6. The Guardian, Brexit: May vows to resign before next phase of negotiations if deal is passed, 28.03, (2019).

7. J. Tapsfield, 'It's been a journey': Theresa May breaks down in tears again behind closed doors minutes after resigning as she is applauded be staff and thanks 'her rock' husband Philip, The Daily Mail, 29.05, (2019).

8. May's emotional farewell kicks off battle for Tory leadership, The Guardian, 24.05, (2019).

9. Theresa May to resign before next phrase of Brexit, The Guardian, 27.03, (2019).

10. E. Malnick, Theresa May determined to push 'legacy' spending demands. The Telegraph, 29.06, (2019).

11. H. Freeman, Theresa May, Margaret Thatcher: spot the difference - and the sexism, 23.07, The Guardian, (2016).

12. K. Ferguson, Theresa May calls Whitehall leaks that branded Jeremy Cordyn too 'frail' to be PM 'unacceptable', The Sun, 1.07, (2019).

13. J. Kirkup, Theresa May interview: 'We're going to give illegal migrants a really hostile reception, The Telegraph, 25.05, (2012).

14. N. Arutyunova, Metaphor and discourse, The theory of metaphor, 5-32, (1990)

15. R. Merrick, Theresa May reveals how her faith in God gives her confidence she is 'doing the right thing', The Independent, 27.11, (2016).

16. Theresa May suffers historic defeat as Tories turn against her, The Guardian, 16.01, (2019).

17. E. Budaev, A. Chudinov, Metaphor in the political interdiscourse, 45, (2006).

18. A. Cowburn, Tory MP Philip Davies submits letter of no confidence in Theresa May, The Independent, 18.07, (2018).

19. A. Woodcock, Theresa May defends committing government to spending billions during final weeks in office, The Independent, 29.06, (2019).

20. Experte: "Russland bereitet sic hunter Putin auf regionale Kriege in Europa vor, Focus online, 14.07, (2019).

21. Spiegel online. Ein bisschen Neustart, 18.08, (2018).

22. P. Stiegnitz, Die großen Lügen der kleinen Politiker? Eine Analyse (2004).

23. M. Zheltukhina, A. Omelchenko, Creating of the political image of Russia in foreign media. The image of Russia in foreign political discourse: stereotypes, myths and metaphors, The materials of International scientific conference, 59-62, (2010).

24. Putins alte Heimat: Welche Pläne der Kreml-Chef in Ostdeutschland verfolgt, Business Insider, 12.06, (2019).

25. Politik. Volles Risiko: Annegret Kramp-Karrenbauer übernimmt Bundeswehr, GMX Magazine, 18.06, (2019).

26. Putin vs. von der Leyen: Warum die neue EU-Chefin nützlich für den Kreml sein könnte, Business Insider, 16.07, (2019).

27. Anführerin der freien Welt? Aber klar doch! Die Zeit online, 16.11, (2016).

28. Putins Ehe mit Ex-Frau Ljudmila Putina, Focus online, 21.01, (2016). 